\title{
COVID-19, gender inequality, and the responsibility of the state
}

\begin{abstract}
Nikki Fortier
Abstract: Previous research has shown that women are disproportionately negatively affected by a variety of socio-economic hardships, many of which COVID-19 is making worse. In particular, because of gender roles, and because women's jobs tend to be given lower priority than men's (since they are more likely to be part-time, lower-income, and less secure), women assume the obligations of increased caregiving needs at a much higher rate. This unfairly renders women especially susceptible to short- and long-term economic insecurity and decreases in wellbeing. Single-parent households, the majority of which are headed by single mothers, face even greater risks. These vulnerabilities are further compounded along the dimensions of race, ethnicity, class, and geography. Drawing upon the philosophical literature on political responsibility and structural injustice (specifically, the work of Iris Marion Young), I argue that while the state may not have had either foresight into, or control over, the disproportionate effect the pandemic would have on women, it can nonetheless be held responsible for mitigating these effects. In order to do so, it must first recognize the ways in which women have been affected by the outbreak. Specifically, policies must take into account the unpaid labor of care that falls on women. Moreover, given that this labor is particularly vital during a global health pandemic, the state ought to immediately prioritize the value of this work by providing financial stimuli directly to families, requiring employers to provide both sick leave and parental leave for at least as long as schools and daycares are inoperational, and providing subsidized emergency childcare.
\end{abstract}

Keywords: Gender inequality, wellbeing, political responsibility, structural injustice, COVID-19 


\section{Practice implications}

1) Elimination of "workfare" policies

Because many lone-parents are forced to leave the formal labor market in order to address the drastic increase in childcare needs resulting from the closures of schools and daycares, workfare policies, which force people to work in the formal market in order to receive welfare benefits, unfairly discriminate against single-parents, the majority of whom are mothers.

2) Provision of emergency childcare

Many parents who rely on a regular income to make ends meet, but especially singlemothers, need emergency, subsidized childcare in order to remain employed.

3) Implementation of paid parental leave

Paid parental leave for both mothers and fathers prevents parents from having to choose between providing an income for their families and childcare for their children. Providing paternity leave has also been shown to have long-term effects on the division of care work.

4) Facilitate transitions to part-time work

Women are far more likely to reduce their paid labor in order to meet increases in childcare obligations. In order to soften the blow to their economic security and wellbeing, states should legally mandate employment benefits for part-time employees, and provide training for employers on how to implement flexible schedules and requirements.

5) Closure of the gender wage gap

As long as women earn less than men, women's jobs will be more disposable than men's. Taking steps toward closing the gender wage gap will help prevent women from assuming a disproportionate burden during economic crises.

\section{Introduction}

Previous research shows that women are disproportionately negatively affected by a variety of socio-economic hardships worldwide (Pearce, 1978; Assassi, 2009; Gill \& Roberts, 2011; Langer et al., 2015), many of which COVID-19 is making worse (Ewing-Nelson, 2020). There is good reason to think that the pandemic is devastating for gender equality, and particularly devastating for women's wellbeing. Economists Alon et al. (2020) convincingly argue that although in previous economic crises, men's employment has been more at risk, several unique factors of this pandemic make women's employment more vulnerable. In practice, it has so far been the case that women have lost the majority of jobs due to COVID-19 (IWPR, 2020). In Canada, for instance, $5 \%$ of women between the ages of $25-54$, but only $2 \%$ of men of the same age, have lost their jobs due to coronavirus (Johnson, 2020).

Women are not only being laid off at higher rates than men; they are also sacrificing their jobs to meet the increased childcare obligations at a higher rate. As schools and daycares shut down, childcare work shifts from the paid economy to the unpaid one. Women already do far more unpaid care work (of both children and adults) and have less free time than men (Mattingly \& Bianchi, 2003; Sayer, 2005; Bettio et al., 2006; Esquivel et al., 2008; Budlender, 2010; Schoonbroodt, 2018), and any increase in care needs will be disproportionately assumed by women (Alon et al., 
2020). ${ }^{1}$ Women tend to bear the burden of this shift both because of social norms regarding who assumes caregiver roles (Floro et al., 2009; Signorelli et al., 2012; Wenham et al., 2020), and because women's jobs tend to be given lower priority since, in almost all economies, they are more likely to have part-time, lower-income, and less secure jobs, with less bargaining power than men (Kim, 2000; Truong, 2000; Carr \& Alter-Chen, 2002; Antonopoulos, 2008; Dejardin \& Owens, 2009; Floro et al., 2009; Sirimanne, 2009; Boniol et al, 2019; Johnson, 2020). It is also worth noting that people with low-wage jobs are less likely to have adequate health insurance, sick leave, access to childcare, and other benefits that protect higher-wage workers from COVID-19 exposures (Poteat et al., 2020). Intersectional oppressions should not be ignored here: Black Americans, for example, are more likely to have low-wage essential service jobs, and thereby assume more risk of both contracting COVID-19, and of dying from it (Yancy, 2020). ${ }^{2}$ Or, for instance, because homeless populations live in congregate living settings both formally (in shelters, for example) and informally (in, for example, encampments and abandoned buildings), and among people who may not have access to regular hygiene resources, they are more likely to contract coronavirus (Tsai \& Wilson, 2020). Consider too a study by Kizilirmak and Memis (2009) which shows that women's (and not men's) responsibilities for care work (and, presumably, any increase in care work needs) intensifies along with the depth of their poverty. The most vulnerable people in our societies are those most at risk.

The increase in unpaid care work is one of the most significant ways that this crisis will harm women, both directly and indirectly. Assuming an unfair share of the burden of unpaid care work produced by our responses to COVID-19 harms women directly because of its effect on mental wellbeing. There is no question that taking on excessive role responsibilities (either in the household, in the workplace, or both) has detrimental effects on psychological wellbeing (Fox \& Nickols, 1983; Gore \& Mangione, 1983; Lowe and Northcott 1988; Nelson \& Burke, 2002). Caregiving responsibilities, in particular, are associated with increased psychological distress (Anthony-Bergstone et al., 1988; George \& Gwyther, 1986; Hoyert \& Seltzer, 1992; Schulz \& Williamson, 1991; Strawbridge et al., 1997; Pinquart \& Sörensen, 2003). It is also worth noting that women experience greater psychological distress in their roles as caregivers than do men (Miller \& Cafasso, 1992; Yee \& Schulz, 2000).

When caregiving needs increase, some will move from full-time to part-time work, while some will stop working altogether (Lilly et al., 2007; Hess et al., 2015; Hess et al. 2020). Women are far more likely than men to move into part-time work (Hegewisch \& Lacarte, 2019), and to stop working altogether (Alon et al., 2020) in order to meet their care obligations. Women who move into part-time work will very likely face a disproportionate psychological burden stemming from work-family conflict, which has been shown to have a negative effect on mental health (Allen et al., 2000; Frone, 2000; Frone et al., 1997; Grzywacz \& Bass, 2003) and on general wellbeing (Grant-Vallone \& Donaldson, 2001; Moen \& Yu, 2000). Similarly, women, singleparents, and caregivers are more likely than others to rush in order to meet their obligations,

\footnotetext{
${ }^{1}$ Some prefer the term "social reproduction" to "care work" (see Kofman, 2012, p. 144). Throughout this paper, by "care work", I am referring to (1) biological reproduction, along with the labor required to maintain a healthy family life (including the affective and emotional burdens that it involves); (2) unpaid production of goods and services (including time volunteered in one's community); and (3) the maintaining and reproduction of culture and ideology which works to stabilize and/or challenge social relations (Hoskyns \& Rai 2007, p. 300, cited in Rai et al., 2014, p. 87).

${ }^{2}$ See Bibbins-Domingo (2020), Hooper et al. (2020), McLeod et al. (2020), Poteat (2020), and Yancy (2020) for other ways in which people of color and ethnic minorities are disproportionately affected by COVID19.
} 
which is also associated with greater work-family conflict (Strazdins et al., 2016). Both rushing and time-poverty have been shown to negatively impact health (Teuchmann et al., 1999; Spinney \& Millward, 2010; Offer \& Schneider, 2011; Strazdins et al., 2016). There is also good reason to think that women will feel the effects of moving into part-time work long after the pandemic ends. Women who transition to part-time work for just one year before moving back to full-time earn up to 10\% less, even 15 years later (Antonopoulos, 2008, p. 25).

Women who exit the paid labor market in order to meet the increase in care obligations also face significant reductions in wellbeing. Unsurprisingly, unemployment and financial strain are cited as causes for increased levels of stress, insecurity, and social exclusion, as well as poorer mental wellbeing (Nordenmark \& Strandh 1999; Giuntoli et al., 2011; Giuntoli et al., 2015; Hiswåls et al., 2017), all of which have been shown to be strongly correlated with decreased health and subjective wellbeing (Duxbury \& Higgins, 2001; Burke, 2002; Verkuyten, 2008). Both men and women in the U.K., for example, have lower life satisfaction when they are involuntarily out of the labor market (Della Giusta et al., 2011). There is also evidence that individual earnings impact one's bargaining power within the household, which in turn decreases her wellbeing because of its effects on self-esteem and respect (Kabeer 2002; Pollak 2005; Seguino, 2006; Floro \& Pichetpongsa, 2010). Along similar lines, some studies show that a person's happiness, lifesatisfaction, or general wellbeing increases with greater economic freedom (Gehring, 2013; Ovaska \& Takashima, 2006; Verme, 2009; Welzel \& Inglehart, 2010, cited in Lambert et al., 2020). Moreover, women whose employment is affected by economic crises return to their pre-crisis work levels more slowly than men (Smith, 2009; ILO, 2010), Longer durations of unemployment are associated with increased negative emotions and poorer wellbeing (Hiswåls et al., 2017). At least one study found that people who remain unemployed for more than a year do not return to the wellbeing level they had before they lost their job (Lucas et al. 2004).

Single-parent households (just under 70\% of which, in the U.S., are headed by single mothers, according to the U.S. Census Bureau, 2019) face even greater risks. Single mothers are forced to choose between having an income and providing childcare. Between February and May of 2020, unemployment of single mothers in the U.S. more than tripled, moving from $4.1 \%$ to $15.9 \%$ (U.S. Bureau of Labor Statistics, 2020). Before the pandemic, single mothers were already more likely to live in more severe poverty, for a longer duration than other groups (Madruga, 2006, cited in Landero Hernández et al., 2009). These risks are further compounded along the dimensions of race and ethnicity. In the U.S., more than half (55.5\%) of all Black families with children and 36.9 percent of Native American families with children are headed by a single mother (Shaw et al. 2020).

In addition, quarantine measures and stay-at-home orders are having devastating effects on people who endure domestic violence, the majority of whom are women (Boserup, 2020). Isolation coupled with additional economic and family stressors are conspiring to create unprecedented global increases in domestic violence, with fewer resources available for those affected by it (Usher et al., 2020; van Gelder et al. 2020).

\section{The Social Connection Model of Political Responsibility}

Once we identify the ways in which women are disproportionately disadvantaged by COVID19 , we need to address the question of what to do about it, and of who is responsible for so doing. I argue that, while everyone has an obligation to address this injustice, the state bears the greatest 
responsibility for so doing. ${ }^{3}$ The account of responsibility upon which I rely does not hold that a person or an entity is responsible for addressing an injustice because they are blameworthy or liable for that injustice. To mount my argument, I instead employ the influential social connection model of political responsibility put forth by Iris Marion Young (1990; 2000; 2003; 2004; 2006; 2011). ${ }^{4}$ This model aims not to hold responsible all and only those who have played some causal role in bringing about an injustice, but to account for the moral requirement to address largescale structural injustices. Structural injustice occurs as a consequence of social processes that put certain groups of people "...under a systematic threat of domination or deprivation of the means to develop and exercise their capacities..." (Young 2006, p. 114). It is crucial to note that whether some state of affairs constitutes a structural injustice does not depend on whether anyone intended any wrongness or injustice; it instead depends only on whether the effect of social practices and processes is the systematic subjugation of a particular group. Knowing that the effect of COVID-19 is that women are systematically disadvantaged in a number of respects is sufficient to know that the pandemic has resulted in structural injustice.

If we cannot look backwards to assess blame or liability, how do we determine who is responsible for addressing the gender inequality exacerbated by the pandemic? Following Young (2000; 2003; 2004; 2006; 2011), Anthony Giddens (1984), and Onora O'Neill (1985; 1996), I appeal to the fact that structural injustice is not a stagnant state of affairs, but an ongoing process that people collectively reproduce by their actions and assumptions. What distinguishes it from cases in which an institution knowingly enacts repressive policies is that structural injustice occurs as the cumulative result of agents acting in pursuit of their uncoordinated goals and interests within the bounds of perfectly acceptable norms and institutional rules (Young, 2011, p.52). In so acting, these agents (likely unknowingly) reproduce the structures that give rise to the injustice. O'Neill (1996, ch.3) argues that we all have moral obligations to others with whom we share a societal structure; in particular, those whose actions we assume as preconditions for our own actions. ${ }^{5}$ For instance, when I buy bread from a grocery store, I assume and rely on the fact that farmers, manufacturers, food inspectors, transporters, and vendors will all have done certain actions that reliably enable me to safely, cheaply, and conveniently buy bread. Young (2000, p.242) writes,

Wherever people act within a set of institutions that connect them to one another by commerce, communications, or consequences of policies, such that systemic interdependencies generate benefits and burdens that would not exist without these institutional relationships, then the people within that set of interdependent institutions stand in relations of justice.

\footnotetext{
${ }^{3}$ My own view is that we are all morally obligated to address injustices, regardless of our connection to them, but for those who are unconvinced, my argument provides reason to think that states have special obligations to do so.

${ }^{4}$ The distinction between the backward-looking "liability model" of responsibility (one which focuses on fault, blame, and liability) and the forward-looking political responsibility is derived from Hannah Arendnt's work (Arendt 1987; 2000).

${ }^{5}$ Charles Beitz (1979) and Thomas Pogge (1992) make similar arguments in order to ground our transnational obligations of justice. Meena Krishnamurthy (2013) argues not that our connections to one another ground our political obligations of justice, but that they ground political solidarity, which is integral to justice (and, in particular, integral to achieving justice in our responses to a pandemic).
} 
She then suggests that the demands of political responsibility are distributed among responsible parties according to who is most powerful and most capable of enacting effective change (Young, 2004, pp.385-7; 2006, pp.126-30; 2011, pp.146-7).

The social connection model of political responsibility is particularly well-suited to address gender inequality, especially the inequality exacerbated by COVID-19. First, there is no question that, even in the best of times, we are all connected to women as a social group by systematic interdependencies, and are thereby all obligated to work toward addressing structural injustices on the basis of gender (Rai et al., 2014). As feminist and gender-aware theorists have long been pointing out, though women's domestic, reproductive, and care work is largely unpaid and unrecognized, it is absolutely essential to a healthy (both global and national) economy (Çağatay \& Özler, 1995; Budlender, 2007; Heckmann \& Masterov, 2007; Heckman, 2008; Harper et al., 2009; for examples of ways in which policy-makers fail to consider the importance of women's work, see Heymann, 2006). We all depend on the unrecognized work of women both intranationally and internationally. ${ }^{6}$ The idea that the state's dependence on women's unpaid labor generates obligations is not new. Economist Nancy Folbre $(1994,2001)$ argues that because women do the work required to maintain and reproduce a healthy pool of labor on which the state depends, the state has a responsibility to address the systemic inequality of women. Our interconnectedness and dependency on the work of women is even more salient, though, as it relates to the additional gender inequality caused by the pandemic. It is well-recognized that the work of women acts as a shock-absorber in times of economic crisis (Elson, 1991, 2002, 2014; Palmer, 1991; González de la Rocha, 1994; Çağatay \& Özler, 1995; Elson \& Çağatay, 2000; Bezanson, 2006; Björkman, 2006; Sulaiman et al., 2009; Razavi \& Staab, 2012; Rai et al., 2014; Harman, 2016). As a society, we thereby assume this work from women in our response to the pandemic. If we accept the thought that we have a political responsibility to correct injustices borne by those whose actions we assume and upon which we depend, it is indisputable that we are all morally obligated to work toward alleviating the structural injustices that women face; particularly those that are made worse by COVID-19. Though our reliance on women in our response to the pandemic means that we all have a moral obligation to act to address the exacerbation of gender inequality, the fact that the state is far more capable of enacting meaningful change than individuals means that the state bears the greatest responsibility to do so. As individuals, we have the collective power to pressure our governments and, to some extent, other governments, to make policies that address this injustice, and we should do everything we can to exercise that power. Governmental intervention is the only way we can begin to address such sweeping structural injustices.

\section{Policies for the Wellbeing of Women}

Single-mothers are one of the groups hit hardest by the effects of the pandemic, and, as a result, we need to prioritize policies that will address their most pressing needs. Schools and daycares have shut down, and millions of single-mothers have been forced to choose between having an income and providing their children with essential care. First, for states that have "workfare" policies in place (which require recipients of welfare to work in order to receive benefits),

\footnotetext{
${ }^{6}$ For example, because women in the West are increasingly becoming employed in the formal sector, there is a corresponding increase in demand for paid care work; a demand that is largely met by women of color and ethnic minority from poorer regions of the world who are often exploited for such work (Heyzer et al., 1994, Parreñas, 2001; Williams, 2001, 2018; Bettio et al., 2006; Williams \& Gavanas, 2008; see also Glenn, 1992; Heymann, 2006).
} 
eliminating them must be a priority (Peck, 2001). Second, there is evidence that access to and use of publicly-funded childcare results in significant increases in subjective wellbeing for women who were previously constrained by the lack of childcare supply (Schmitz, 2020). Accordingly, governments must provide high-quality childcare to all families. Doing so is especially vital for the wellbeing of single-parents as it will allow them to maintain the family's only source of income. To the same end, employers should be required to provide caregivers with emergency paid family leave. States should also prioritize direct payments to single-parents who have already been forced into unemployment. Aside from the obvious contribution to wellbeing associated with the ability to meet one's basic needs, some evidence suggests that generous unemployment benefits such as these offset the psychological distress associated with unemployment (Di Tella et al., 2003).

In households with both a mother and a father, the provision of emergency paid family leave would not only allow mothers an opportunity to remain employed (thus avoiding the long-term negative impacts on wellbeing that are associated with unemployment), but it would also encourage fathers to meet more of the increased demand for care work. In fact, there is evidence that having parental leave available to fathers may have long-term effects on the division of household and childcare labor (Nepomnyaschy \& Waldfogel, 2007; Patnaik, 2019; Tanaka \& Waldfogel, 2007; Huerta et al., 2013; Almqvist \& Duvander, 2014; Bünning, 2015; Farré \& González, 2019).

Because women are far more likely to reduce their paid work in response to the increased need for childcare, the state needs to increase the benefits that employers are required to provide for part-time employees, including the provision of paid sick leave, parental leave, and health insurance (Shaw et al., 2020). We should also look for additional ways to accommodate women's increased need for part-time work. Some researchers suggest that implementing organizational training that teaches employers how to provide more job flexibility (in terms of allowing employees to make their own hours and of providing the option of working from home) would substantially benefit employees who have caregiving responsibilities by reducing stress and psychological distress (Kassek et al., 2019).

While policies like these are crucial in the short-term to alleviate some of the unfair burden that COVID-19 forces women to assume, larger-scale economic reform is necessary to address gender inequality in the long-term (Antonopoulos, 2008), and to prevent future economic crises from disproportionately affecting women. One of the first things we need to do for long-term improvement on gender equality is to formally value unpaid women's work (Hoskyns \& Rai 2007; Folbre, 2012). This not only acknowledges the value of unpaid care work, but also allows and encourages policy-makers to take it into account in their deliberations.

It is widely recognized that if policies are to address gender inequality as it relates to the disproportionate burden of care that women assume worldwide, they must provide for care services, paid leaves, and flexible working hours (Daly \& Rake, 2003; Gornick \& Meyers, 2003; Bettio \& Plantenga, 2004; Leitner \& Wroblewski, 2006; Lewis, 2006, Craig \& Mullan, 2010; Ghodsee, 2018). Governments should implement permanent policies that are designed to encourage an equal distribution of unpaid work among men and women. These can include policies that

...limit the maximum number of weekly employment hours, require fathers to take paternity leave, offer extended job leaves with partial coverage of wages for parents of young children, reduce differences between full-time and part-time work in terms of pay and access to benefits, provide family allowances, and base social security or 
pension credits on caregiving instead of marriage to a wage earner, appear to reduce the economic penalties associated with caregiving and lessen time pressures associated with juggling paid and unpaid work responsibilities (Sayer, 2005, p. 298).

Finally, we all need to continue to work towards closing the gender wage gap. As long as it makes economic sense for women's paid labor, rather than men's, to decrease during economic crises like the one caused by the pandemic, it will be the case that women assume more of the unpaid caregiving duties, causing them to have reduced economic freedom and bargaining power, and thus reduced wellbeing (Hess, et al., 2020). On top of protecting women from unemployment resulting from future economic crises, there is good reason to think that eliminating the wage gap would increase subjective wellbeing (Oishi et al., 2011; Oishi \& Diener, 2014).

COVID-19 exacerbates existing gender inequality in a way that cannot be ignored. While it is imperative to enact policies that alleviate the needs created by the pandemic, we ought not stop there. We need to treat this as an opportunity to get clear not only about the inequalities and injustices that women face worldwide, but also on what tangible things our institutions can do to address them. The goal should not just be to help women survive COVID-19, but to create a world in which they can flourish. This crisis provides us with valuable context in which to explore the complex interactions between macroeconomic conditions, legislative policies, intersectional oppressions, wellbeing, and gender belief systems. The relationship between state policies and gender dynamics is especially pertinent to women's wellbeing because of the state's unique ability to enact legislation to catalyze meaningful change. Policies, or the lack thereof, can contribute to shaping cultural norms and beliefs, and can have intergenerational, long-lasting implications (Cooke \& Baxter, 2010). The hope is that the implementation of the long-term policies recommended above will help reshape gender norms, particularly as they relate to care work, so as to create a more equal society. Even if the only thing that changed were our cultural and societal gender norms surrounding care work, we could reasonably expect a significant effect on women's wellbeing and liberty. If there were no gendered expectations about who would assume care work, there would be, among other things, fewer single mothers, a less significant wage gap, and a more equal division of unpaid labor. The less that women are compelled to assume unpaid care work, the more they are free to participate in labor that accords with their desires, values, and interests. Governments' failures to enact legislative intervention that promotes gender equality needs to be seen not as respecting personal liberty, but as a choice to maintain a society that we know is actively repressive of and harmful to women.

Continued research is required on the specifics, logistics and efficacy of policies that aim to address gender inequality. In particular, there is a dire need for more wellbeing research that moves beyond an individualistic approach to the promotion of women's wellbeing (and of wellbeing in general). Governmental and social institutions are uniquely well-positioned not only epistemically, but also in their ability to have significant impacts on the wellbeing of their populations. Accordingly, more researchers need to broaden their perspectives on what is possible and reasonable to expect from those institutions as it relates to the promotion of the wellbeing of marginalized populations. More research is necessary to adequately understand the impact of different policies on people along the dimensions of gender, race, ability, sexual orientation, geography, and class. We should be sure to avoid adopting a monolithic view of women: We cannot expect a one-size-fits-all approach to adequately address the diverse needs of diverse populations. One study, for instance, found that availability of flexible work arrangements was associated with higher job satisfaction and less work-family conflict in North America, Australia, New Zealand, and Great Britain, but not in Latin American and Asian 
countries (Masuda et al., 2012). The concerns of women differ along the dimensions previously mentioned, and our policies should be created with this in mind. We also need to be ready and willing to adapt our response to the pandemic as our understanding of its repercussions evolves. The effects of the pandemic on women's wellbeing is still unfolding, and as such, monitoring its impact is an ongoing project. The effects explored in this article should in no way be taken to be exhaustive.

\section{Conclusion}

Women are disproportionately negatively affected by the response to COVID-19. The effects of this unfair burden may be devastating and long-lasting for millions of women. Though we are all obligated to do what we can to address this structural injustice, the state bears the greatest obligation because it is uniquely positioned to effectuate meaningful change. In the short-term, it should prioritize implementing urgent legislation that will help those most at risk. In the longterm, policy-makers need to create effective interventions that reduce gender inequality. One of the most promising ways that they can do so is by designing policies that aim to change cultural norms and gendered expectations regarding care work. These policies should equalize the division of unpaid care work in order to not only prevent future economic crises from exacerbating the onerous injustices that women face worldwide, but to also create a society in which women can flourish. As citizens, we need to hold our social institutions accountable for promoting the wellbeing of marginalized groups, and to learn to expect more from them.

\section{Acknowledgments}

For their helpful feedback, I would like to thank Nicole Dular, David Sobel, Ben Bradley, Brian Fortier, Deb Raven, and especially David Pizarro.

\section{Authors}

Nikki Fortier

Syracuse University

nfortier@syr.edu

\section{Publishing Timeline}

Received 30 August 2018

Accepted 16 November 2019

Published 13 August 2020

\section{References}

Allen, T.D., Herst, D.E.L., Bruck, C.S., Sutton M. (2000). Consequences associated with work-to-family conflict: A review and agenda for future research. Journal of Occupational Health Psychology, 5(2), 278- 308.

Almqvist, A. L., \& Duvander, A. Z. (2014). Changes in gender equality? Swedish fathers' parental leave, division of childcare and housework. Journal of Family Studies, 20(1), 19-27.

Alon, T. M., Doepke, M., Olmstead-Rumsey, J., \& Tertilt, M. (2020). The Impact of COVID-19 on Gender Equality. National Bureau of Economic Research, Working Paper 26947, 1-37.

Anthony-Bergstone, C. R., Zarit, S. H., \& Gatz, M. (1988). Symptoms of psychological distress among caregivers of dementia patients. Psychology and Aging, 3(3), 245.

Antonopoulos, R. (2008). The unpaid care workpaid work connection, working paper, no. 541. Annandale-onHudson, USA: Levy Economics Institute of Bard College. 
Arendt, H. (1987). Collective responsibility in Amor mundi: Explorations in the faith and thought of Hannah Arendt, (ed.) J.W. Bernauer. Boston, USA: Martinus Nijhoff Publishers, 43-50.

Arendt, H. (2000). Organized guilt and universal responsibility in The portable Hannah Arendt, (ed.) P. Baehr. London, UK: Penguin Books, 146-57.

Assassi, L. (2009). The Gendering of Global Finance. Basingstoke, UK: Palgrave Macmillian.

Bakker, I. (2007). Social reproduction and the constitution of a gendered political economy. New Political Economy, 12(4), 541-56.

Beitz, C. (1979). Political theory and international relations. Princeton, USA: Princeton University Press.

Bettio, F., \& Plantenga, J. (2004). Comparing care regimes in Europe. Feminist Economics, 10(1), 85-113.

Bettio F., Simonazzi A. \& Villa P. (2006). Change in care regimes and female migration: The care drain in the Mediterranean. Journal of European Social Policy, 16(3), 271-285.

Bezanson, K. (2006). The neo-liberal state and social reproduction: Gender and household insecurity in the late 1990s. In Social reproduction: Feminist political economy challenges neo-liberalism, (ed.) Bezanson, K. \& Luxton, M., 173-214. Montreal: McGill-Queens' University Press.

Bibbins-Domingo K. (2020). This time must be different: Disparities during the COVID-19 pandemic. Annals of Internal Medicine. doi: 10.7326/M20-2247.

Björkman, M. (2006). Income shocks and gender gaps in education: Evidence from Uganda. Stockholm, SE: Institute for International Economic Studies, University of Stockholm.

Boniol M, McIsaac M, Xu L, Wuliji T, Diallo K, Campbell J. (2019). Gender equity in the health workforce: analysis of 104 countries. Working paper 1. Geneva, CH: World Health Organization.

Boserup, B., McKenney, M. \& Elkbuli, A. (2020). Alarming trends in US domestic violence during the COVID-19 pandemic. American Journal of Emergency Medicine. https://doi.org/10.1016/j. ajem.2020.04.077

Budlender, D. (2007). A critical review of selected time use surveys. Gender and Development Research Programme, Political and Social Economy of Care Series, paper no. 2. Geneva, CH: UNRISD.

Budlender, D. (2010). Time use studies and unpaid care work. New York, USA: Routledge.

Bünning, M. (2015). What happens after the 'daddy months'? Fathers' involvement in paid work, childcare, and housework after taking parental leave in Germany. European Sociological Review, 31(6), 738-748.

Burke, R. J. (2002). Work stress and women's health: Occupational status effects. Journal of Business Ethics, 91-102.

Çağatay, N. \& Özler, Ş. (1995). “Feminization of the labour force: The effects of long-term development and structural adjustment". World Development, 23(11), 1883-1894.

Carr, M. \& Alter-Chen, M. (2002). Globalization and the informal economy: How global trade and investment impact on the working poor, employment sector, working paper on the informal economy. Geneva, $\mathrm{CH}$ : International Labour Organisation.

Cooke, L. P. \& Baxter, J. (2010). " Families" in international context: comparing institutional effects across western societies. Journal of Marriage and Family, 516-536.

Craig, L. \& Mullan, K. (2010). Parenthood, gender and work-family time in the United States, Australia, Italy, France, and Denmark. Journal of Marriage and Family, 72, 1344-1361.

Daly, M., \& Rake, K. (2003). Gender and the welfare state. Cambridge, UK: Polity Press.

Dejardin A.K. \& Owens J. (2009). Asia in the global economic crisis: Impacts and responses from a gender perspective. Bangkok, TH: International Labour Organization Regional Office for Asia and the Pacific. 
Della Giusta, M., Jewell, S.L. \& Kambhampati, U.S. (2011). Gender and life satisfaction in the UK. Feminist Economics, 17(3), 1-34.

Di Tella, R., MacCulloch, R. J., \& Oswald, A. J. (2003). The macroeconomics of happiness. Review of Economics and Statistics, 85(4), 809-827.

Duxbury, L., \& Higgins, C. (2001). Work-life balance in the new millennium: Where are we? Where do we need to go? Discussion paper no. W/12. Ottawa, CA: Canadian Policy Research Networks.

Edholm, F., Harris, O., Young, K. (1978). Conceptualizing women. Critique of Anthropology, 3(9-10), 10131.

International Labour Office. (2010). Women in labour markets: measuring progress and identifying challenges. Geneva, CH. http://www.ilo.org/wcmsp5/groups/public/---ed emp/---emp elm/--trends/documents/publication/wcms 123835.pdf.

Elson, D. (Ed.). (1995). Male bias in the development process. Manchester, UK: Manchester University Press.

Elson, D. (1998). The economic, the political and the domestic: Businesses, states and households in the organisation of production. New Political Economy, 3(2), 189-208.

Elson, D. (2002). International financial architecture: A view from the kitchen. Femina Politica, 1, $26-37$.

Elson, D. (2014). Economic crises from the 1980s to the 2010s: A gender analysis. In New frontiers in feminist political economy, (ed.) Rai, S. \& Waylen, G., 189-212. London, UK: Routledge.

Elson, D. \& Çağatay, N. (2000). The social content of macroeconomic policies. World Development, 28(7), 1347-1364.

Esquivel, V., Budlender, D., Folbre, N. \& Hirway, I. (2008). Explorations: Time-use surveys in the South. Feminist Economics, 14(3), 107-52.

Ewing-Nelson, C. (2020, February). Part-time workers are paid less, have less access to benefits - and most are women. National Women's Law Center. https://nwlcciw49tixgw5lbab.stackpathdns.com/wp-content/uploads/2020/02/Part-Time-Workers-Factsheet2.26.20.pdf.

Farré, L. \& González, L. (2019). Does paternity leave reduce fertility? Journal of Public Economics, 172, 5266.

Floro, M.S. \& Pichetpongsa, A. (2010). Gender, work intensity, and well-being of Thai home-based workers. Feminist Economics, 16(3), 5-44. DOI: 10.1080/13545701.2010.499657

Floro, M. S., Tornqvist, A. \& Tas, E.O. (2009). The impact of the economic crisis on women's economic empowerment. Swedish International Development Agency Working Paper Series.

Folbre, N. (1994). Who pays for the kids? Gender and the structures of constraint. New York, USA: Routledge. Folbre, N. (2001). The invisible heart: Economics and family values. New York, USA: The New Press.

Folbre, Nancy. (2012). Valuing Care. In For love and money: Care provision in the United States, (ed.) Folbre, N. New York, USA: Russell Sage Foundation, 92-111.

Frone, M.R. (2000). Work-family conflict and employee psychiatric disorders: The national comorbidity survey. Journal of Applied Psychology, 85(6), 888-895.

Frone, M.R., Yardley, J.K., Markel, K.S. (1997). Developing and testing an integrative model of the workfamily interface. Journal of Vocational Behavior, 50(2), 145-167.

Gehring, K. (2013). Who benefits from economic freedom? Unraveling the effect of economic freedom on subjective well-being. World Development, 50, 74-90.

George, L. K., \& Gwyther, L. P. (1986). Caregiver well-being: a multidimensional examination of family caregivers of demented adults. The Gerontologist, 26(3), 253-259.

Ghodsee, K. (2018). Why women have better sex under socialism: And other arguments for economic independence. New York, USA: Nation Books. 
Giddens, A. (1984). The constitution of society. Berkeley, USA: University of California Press.

Gill, S. \& Roberts, A. (2011). Macroeconomic governance, gendered inequality and global crises. In Questioning financial governance from a feminist perspective, (eds.) Young, B., Bakker, I. \& Elson, D., 154-171. New York, USA: Routledge.

Giuntoli G., South J., Whilte J. (2011). The impact of involuntary unemployment on mental well-being at a time of economic recession and the role of community interventions to strengthen people's resilience. Paper presented at the Social Policy Conference, July 4-6; Lincoln, UK.

Giuntoli G., Hughes S., Karban K., South J. (2015). Towards a middle-range theory of mental health and well-being effects of employment transitions: Findings from a qualitative study on unemployment during the 2009-2010 economic recession. Health, 19, 389-412.

Glenn, E.N. (1992). From servitude to service work: The historical continuities of women's paid and unpaid reproductive labor. Signs, 18(1), 1-44.

González de la Rocha, M. (1994). The resources of poverty: Women and survival in a Mexican city. Cambridge, USA: Blackwell Publishers.

Gore, S., \& Mangione, T. W. (1983). Social roles, sex roles and psychological distress: Additive and interactive models of sex differences. Journal of Health and Social Behavior, 300-312.

Gornick, J. C., \& Meyers, M. K. (2003). Families that work: Policies for reconciling parenthood and employment. Russell Sage Foundation.

Grant-Vallone, E. J., \& Donaldson, S. I. (2001). Consequences of work-family conflict on employee wellbeing over time. Work \& Stress, 15(3), 214-226.

Grzywacz, J. G., \& Bass, B. L. (2003). Work, family, and mental health: Testing different models of workfamily fit. Journal of Marriage and Family, 65(1), 248-261.

Harper, C., Jones, N. and McKay, A. (2009). Including children in policy responses to economic crises: Lessons from the past and policies for a sustainable future. Overseas development institute and UNICEF synthesis conference paper.

Harman, S. (2016). Ebola, gender and conspicuously invisible women in global health governance. Third World Quarterly, 37(3), 524-541.

Heckman, J.J. (2008). Schools, skills, and synapses. Economic Inquiry, 46(3), 289-324.

Heckman, J.J. and D.V. Masterov (2007). The productivity argument for investing in young children, working paper 13016. Cambridge, UK: National Bureau of Economic Research.

Hegewisch, A., \& Lacarte, V. (2019). Gender inequality, work hours, and the future of work. Washington, DC: Institute for Women's Policy Research. https://iwpr.org/publications/gender-inequality-workhours-future-of-work/

Hess, C., Milli, J., Hayes, J. \& Hegewisch, A. (2015). The status of women in the states: 2015. IWPR Report \#C400. Washington, DC: Institute for Women's Policy Research. http://statusofwomendata.org/wp-content/uploads/2015/09/PDF-of-final-Work-Family-chapter-94-2015.pdf

Hess, C., Ahmed, T. \& Hayes, J. (2020, January). Providing unpaid household and care work in the United States: Uncovering inequality. IWPR \#C487. Washington, DC: Institute for Women's Policy Research. https://iwpr.org/wp-content/uploads/2020/01/IWPR-Providing-Unpaid-Household-and-CareWork-in-the-United-States-Uncovering-Inequality.pdf

Heymann, J. (2006). Forgotten families: Ending the growing crisis confronting children and working parents in the global economy. New York, USA: Oxford University Press.

Heyzer N., Lycklama A., Nijeholt G. \& Weerakon N. (1994). The trade in domestic workers, vol. 1. London, UK: Zed Press. 
Hiswåls, A. S., Marttila, A., Mälstam, E., \& Macassa, G. (2017). Experiences of unemployment and wellbeing after job loss during economic recession: Results of a qualitative study in east central Sweden. Journal of Public Health Research, 6(3).

Hooper, M. W., Napoles, A. M., Pérez-Stable, E. J. (2020). COVID-19 and racial/ethnic disparities. JAMA. Advance online publication.

Hoskyns, C. \& Rai, S. M. (2007). Recasting the international political economy: Counting women's unpaid work. New Political Economy, 12(3), 297-317.

Hoyert, D. L., \& Seltzer, M. M. (1992). Factors related to the well-being and life activities of family caregivers. Family Relations, 74-81.

Huerta, M. D. C., Adema, W., Baxter, J., Han, W. J., Lausten, M., Lee, R., \& Waldfogel, J. (2013). Fathers' leave, fathers' involvement and child development: Are they related? Evidence from four OECD countries (No. 140). OECD Publishing.

Institute for Women's Policy Research (2020). Dramatic Decline in Employment Hits Women Even More Severely Than Men. IWPR\# Q082. https://iwpr.org/wp-content/uploads/2020/05/QF-BreadwinnerMothers-by-Race-FINAL.pdf.

Johnson, K. (2020, April 9). Canadian youth, women hit hard by massive coronavirus-related job losses. Reuters. https:/www.reuters.com/article/us-canada-economy-employment-youth/canadian-youth-womenhit-hard-by-massive-coronavirus-related-job-losses-idUSKCN21R3DE

Kabeer, N. (2002). The power to choose: Bangladeshi women and labor market decisions in London and Dhaka. London, U.K.: Verso.

Kim, M. (2000). Women paid low wages: Who they are and where they work. Monthly Labor Review (September), 26-30.

Kizilirmak, B., \& Memis, E. (2009). The unequal burden of poverty on time use, working paper, no. 572. Annandale-on-Hudson, USA: Levy Economics Institute of Bard College

Kofman E. (2012). Rethinking care through social reproduction: Articulating circuits of migration. Social Politics, 19(1), 142-157.

Kossek, E.E., Thompson, R.J., Lawson, K.M., Bodner, T., Perrigino, M.B., Hammer, L.B., Buxton, O. M., Almeida, D.M.,Moen, P., Hurtado, D., Wipfli, B., Berkman, L. \& Bray, J.W. (2019). Caring for the elderly at work and home: Can a randomized organizational intervention improve psychological health?" (2019). Journal of Occupational Health Psychology, 24(1), 36-54.

https://doi.org/10.1037/ocp0000104

Krishnamurthy, M. (2013). Political solidarity, justice and public health. Public Health Ethics, 6(2), $129-141$. Lambert, L., Lomas, T., van de Weijer, M. P., Passmore, H. A., Joshanloo, M., Harter, J., Ishikawa, Y., Lai, A., Kitagawa, T., Chen, D., Kawakami, T., Miyata, H., \& Diener, E. (2020). Towards a greater global understanding of wellbeing: A proposal for a more inclusive measure. International Journal of Wellbeing, 10(2), 1-18. doi:10.5502/ijw.v10i2.1037

Landero Hernández, R., Estrada Aranda, B., González Ramírez, M.T. (2009). Depression and quality of life for women in single-parent and nuclear families. The Spanish Journal of Psychology, 12(1), 171183.

Langer, A., Meleis, A., Knaul, F. M., Atun, R., Aran, M., Arreola-Ornelas, H., et al. (2015). Women and health: the key for sustainable development. The Lancet, 386, 1165-210.

Leitner, A., \& Wroblewski, A. (2006). Welfare states and work-life balance: Can good practices be transferred from the Nordic countries to conservative welfare states?. European Societies, 8(2), 295317.

Lewis, J. (2006). Gender and welfare in modern Europe. Past and Present, 1(Suppl.), 39-54. 
Lilly, M. B., Laporte, A, \& Coyte, P.C. (2007). Labor market work and home care's unpaid caregivers: A systematic review of labor force participation rates, predictors of labor market withdrawal, and hours of work. Milbank Quarterly 85(4), 641-690.

Lowe, G. S., \& Northcott, H. C. (1988). The impact of working conditions, social roles, and personal characteristics on gender differences in distress. Work and Occupations, 15(1), 55-77.

Lucas, R. E., Clark, A. E., Georgellis, Y., \& Diener, E. (2004). Unemployment alters the set point for life satisfaction. Psychological Science, 15(1), 8-13.

Madruga, I. (2006). Monoparentalidad y política familiar. Madrid, ES: CIS/Siglo XXI.

Masuda, A. D., Poelmans, S. A. Y., Allen, T. D., Spector, P. E., Lapierre, L. M., Cooper, C. L., Abarca, N., Brough, P., Ferreiro, P., \& Fraile, G. (2012). Flexible work arrangements availability and their relationship with work-to-family conflict, job satisfaction, and turnover intentions: A comparison of three country clusters. Applied Psychology: An International Review, 61(1), 1-29.

Mattingly, M.J. and Bianchi, S.M. (2003). Gender differences in the quantity and quality of free time. Social Forces, 81(3), 999-1030.

McLeod, M., Gurney, J., Harris, R., Cormack, D., \& King, P. (2020). COVID-19: We must not forget about Indigenous health and equity. Australian and New Zealand Journal of Public Health. doi: 10.1111/1753-6405.13015

Miller, B., \& Cafasso, L. (1992). Gender differences in caregiving: fact or artifact? The Gerontologist, 32(4), 498-507.

Moen, P., \& Yu, Y. (2000). Effective work/life strategies: Working couples, work conditions, gender, and life quality. Social Problems, 47(3), 291-326.

Nelson, D. L., \& Burke, R. J. (2002). Gender, work stress, and health (pp. xii-260). American Psychological Association.

Nepomnyaschy, L. \& Waldfogel, J. (2007). Paternity leave and fathers' involvement with their young children. Community, Work E Family, 10(4), 427-453.

Nickols, S. Y., \& Fox, K. D. (1983). Buying time and saving time: Strategies for managing household production. Journal of Consumer Research, 10(2), 197-208.

Nordenmark M. \& Strandh M. (1999). Towards a sociological understanding of mental well-being among the unemployed: The role of economic and psychosocial factors. Sociology, 33, 577- 97.

Offer, S. \& Schneider, B. (2011). Revisiting the gender gap in time use patterns. American Sociological Review, 76(6), 809-33.

Oishi, S., \& Diener, E. (2014). Can and should happiness be a policy goal?. Policy Insights from the Behavioral and Brain Sciences, 1(1), 195-203.

Oishi, S., Kesebir, S., \& Diener, E. (2011). Income inequality and happiness. Psychological Science, 22, 10951100.

O’Neill, O. (1985). Faces of hunger. London, UK: Allen and Unwin.

O’Neill, O. (1996). Toward justice and virtue. Cambridge, UK: Cambridge University Press.

Ovaska, T., \& Takashima, R. (2006). Economic policy and the level of self-perceived well-being: An international comparison. The Journal of Socio-Economics, 35(2), 308-325.

Palmer, I. (1991). Gender and population in the adjustment of African economies: Planning for change. Women, work and development series no. 19, International labour organization, Geneva.

Patnaik, A. (2019). Reserving time for daddy: the consequences of fathers' quotas. Journal of Labor Economics, 37(4), 1009-1059.

Parreñas, R. (2001). Servants of globalization. Stanford, USA: Stanford University Press.

Peck, J. (2001). Workfare States. New York, USA: Guilford. 
Picchio, A. (1992). Social reproduction: The political economy of the labour market. Cambridge, UK: Cambridge University Press.

Pinquart, M., \& Sörensen, S. (2003). Differences between caregivers and noncaregivers in psychological health and physical health: a meta-analysis. Psychology and Aging, 18(2), 250.

Pogge, T.W. (1992). Cosmopolitanism and sovereignty. Ethics, 103(1), 48-75.

Pollak, R. A. (2005). Bargaining power in marriage: Earnings, wage rates and household production (No. w11239). National Bureau of Economic Research.

Poteat, T., Millett, G., Nelson, L., Beyrer, C. (2020). Understanding COVID-19 risks and vulnerabilities among black communities in America: The lethal force of syndemics. Annals of Epidemiology, 47, 13. https://doi.org/10.1016/j.annepidem.2020.05.004

Rai, S. M., Hoskyns, C., \& Thomas, D. (2014). Depletion: The cost of social reproduction. International Feminist Journal of Politics, 16(1), 86-105.

Razavi, S. \& Staab, S. (2012). Introduction: Global variations in the political and social economy of care worlds apart? In Global variations in the political and social economy of care: Worlds apart? (eds.) Razavi, S. \& Staab, S., 1-25. London: Routledge.

Razavi, S. (2007). The political and social economy of care in a development context. Geneva: United Nations Research Institute for Social Development (UNRISD).

Sayer, L.C. (2005). Gender, time, and inequality: Trends in women's and men's paid work, unpaid work, and free time. Social Forces, 84(1), 285-304.

Schmitz, S. (2020). The impact of publicly funded childcare on parental well-being: Evidence from cut-off rules. European Journal of Population, 36, 171-196. https://doi.org/10.1007/s10680-019-09526-z

Schoonbroodt, A. (2018). Parental child care during and outside of typical work hours. Review of the Economics of the Household, 16, 453-476.

Schulz, R., \& Williamson, G. M. (1991). A 2-year longitudinal study of depression among Alzheimer's caregivers. Psychology and Aging, 6(4), 569.

Seguino, S. (2005). Gender inequality in a globalizing world, working paper, no. 426. Annandale-on-Hudson, USA: Levy Economics Institute of Bard College.

Seguino, S. (2006). Taking gender differences in bargaining power seriously: Equity, living wages, and labor standards. In Feminist perspectives on gender and the world bank, (eds.) Kupier, E. and Barker, D., 94-116. London, U.K.: Routledge.

Shaw, E., Mason, C.N., Lacarte, V. \& Jauregui, E. (2020). Holding Up Half the Sky: Mothers as Workers, Primary Caregivers, \& Breadwinners During COVID-19. IWPR Fact Sheet Q081. Washington, USA: Institute for Women's Policy Research. https://iwpr.org/wp-content/uploads/2020/05/Holding-UpHalf-the-Sky-Mothers-as-Breadwinners.pdf

Signorelli, M., Choudhry, M. \& Marelli, E. (2012). The impact of financial crises on female labor. European Journal of Development Research, 24(3), 413-433.

Smith, M. (2009). Analysis note: Gender equality and recession. Commissioned by Directorate-General for Employment, Social Affairs and Equal Opportunities of the European Commission.

Spinney, J. \& Millward, H. (2010). Time and money: A new look at poverty and the barriers to physical activity in Canada. Social Indicators Research, 99(2), 341-56.

Strawbridge, W. J., Wallhagen, M. I., Shema, S. J., \& Kaplan, G. A. (1997). New burdens or more of the same? Comparing grandparent, spouse, and adult-child caregivers. The Gerontologist, 37(4), 505510.

Strazdins, L., Welsh, J., Korda, R., Broom, D., Paolucci, F. (2016). Not all hours are equal: Could time be a social determinant of health? Sociology of Health $\mathcal{E}$ Illness, 38(1), 21-42. 
Sulaiman M., Parveen M., Das N.C. (2009). Impact of the food price hike on nutritional status of women and children. Dhaka, BD: BRAC.

Tanaka, S., \& Waldfogel, J. (2007). Effects of parental leave and work hours on fathers' involvement with their babies: Evidence from the millennium cohort study. Community, Work E Family, 10(4), 409426.

Teuchmann, K., Totterdell, P. \& Parker, S. (1999). Rushed, unhappy, and drained: An experience sampling study of relations between time pressure, perceived control, mood and emotional exhaustion in a group of accountants. Journal of Occupational Health Psychology, 4(1), 37-54.

Truong, T.A. (2000). A feminist perspective on the Asian miracle and crisis: enlarging the conceptual map of human development. Journal of Human Development, 1(1),159-64.

Tsai, J. \& Wilson, M. (2020). COVID-19: A potential public health problem for homeless populations. The Lancet. https://doi.org/10.1016/ S2468-2667(20)30053-0

U.S. Bureau of Labor Statistics (2019). Labor Force Statistics from the Current Population Survey. https://www.bls.gov/cps/cpsaat10.htm.

U.S. Bureau of Labor Statistics. (2020, May 8). Employment situation summary. Economic News Release, May 8. https://www.bls.gov/news.release/empsit.nr0.htm

U.S. Census Bureau (2019). Table HH-1. Households by Type: 1940 to Present. Retrieved from https://www2.census.gov/programs-surveys/demo/tables/families/time-series/households/hh1.xls.

Usher, K., Bhullar, N., Durkin, J., Gyamfi, N., \& Jackson, D. (2020). Family violence and COVID-19: Increased vulnerability and reduced options for support. International Journal of Mental Health Nursing. https://doi.org/10.1111/inm.12735

van Gelder, N., Peterman, A., Potts, A., O’Donnell, M., Thompson, K., Shah, N. \& Oertelt-Prigione, S. (2020). COVID-19: Reducing the risk of infection might increase the risk of intimate partner violence. EClinicalMedicine. doi: 10.1016/ j.eclinm.2020.100348.

Verkuyten, M. (2008). Life satisfaction among ethnic minorities: The role of discrimination and group identification. Social Indicators Research, 89(3), 391-404. https://doi.org/10.1007/s11205-008-9239-2

Verme, P. (2009). Happiness, freedom and control. Journal of Economic Behavior and Organization, 71, 146161. https://doi.org/10.1016/j.jebo.2009.04.008

Welzel, C., \& Inglehart, R. (2010). Agency, values, and well-being: A human development model. Social Indicators Research, 97, 43-63. https://doi.org/10.1007/s11205-009-9557-z

Wenham, C., Smith, J., Morgan, R. (2020) COVID-19: The gendered impacts of the outbreak. The Lancet, 395(10227), 846-848. doi:10.1016/S0140-6736(20)30526-2

Williams F. \& Gavanas A. (2008). The intersection of child care regimes and migration regimes: A threecountry study. In: Lutz H. (ed.) Migration and Domestic Work: A European Perspective on a Global Theme. Farnham, UK: Ashgate.

Williams, F. (2001). Trends in women's employment, domestic service, and female migration in Europe: An uncomfortable ménage à trois, paper presented to the Royal Netherlands Academy of Arts and Sciences Colloquium, Solidarity between the Sexes and the Generations: Transformations in Europe, June 28 and 29, Amsterdam.

Williams, F. (2018). Care: Intersections of scales, inequalities and crises. Current sociology monograph, 66(4), 547-561.

Yancy, C.W. (2020). COVID-19 and African Americans. JAMA, 323(19), 1891-1892. doi:10.1001/jama.2020.6548

Yee, J. L., \& Schulz, R. (2000). Gender differences in psychiatric morbidity among family caregivers: A review and analysis. The Gerontologist, 40(2), 147-164. 
Young, I. M. (1990). Justice and the politics of difference. Princeton, USA: Princeton University Press.

Young, I.M. (2000). Inclusion and democracy. New York, USA: Oxford University Press.

Young, I.M. (2003). From guilt to solidarity: Sweatshops and political responsibility. Dissent 50(2), 39-44.

Young, I.M. (2004). Responsibility and global labor justice. The Journal of Political Philosophy 12(4), 365-388.

Young, I.M. (2006). Responsibility and global justice: A social connection model. Social Philosophy and Policy Foundation 23(1), 102-130.

Young, I.M. (2011). Responsibility for justice. New York, USA: Oxford University Press. 